\title{
Analisis dan Perancangan Simulasi Perbandingan Kinerja Jaringan Komputer Menggunakan Metode Protokol Routing Statis, Open Shortest Path First (OSPF) dan Border Gateway Protocol (BGP) (Studi Kasus Tanri Abeng University)
}

\author{
Sahril Amuda ${ }^{1}$, Muhamad Femy Mulya ${ }^{2}$, Felix Indra Kurniadi ${ }^{3}$ \\ ${ }^{1}$ Program Studi Teknik Informatika, Tanri Abeng University, Jakarta, Indonesia \\ sahril.amuda@student.tau.ac.id \\ ${ }^{2}$ Program Studi Sistem Informasi, Tanri Abeng University, Jakarta, Indonesia \\ femy.mulya@tau.ac.id \\ ${ }^{3}$ Program Studi Teknik Informatika, Tanri Abeng University, Jakarta, Indonesia \\ felixindra@tau.ac.id
}

Diterima : 23 Februari 2021

Disetujui : 28 Maret 2021

\begin{abstract}
Jaringan adalah dua atau lebih perangkat komunikasi yang menggunakan media internet berbasis kabel atau nirkabel. Di Tanri Abeng University, topologi jaringan dirancang berdasarkan topologi perutean statis. Topologi ini cukup sederhana tetapi membutuhkan proses routing manual. Ini mengarah pada situasi yang rumit ketika ada penambahan jaringan baru. Konfigurasi tabel routing dari jaringan baru cukup sulit. Untuk mengatasi masalah tersebut, diusulkan suatu pendekatan berbasis routing dinamis untuk mendesain ulang topologi jaringan di Universitas Tanri Abeng. Kinerja pengiriman paket data dievaluasi untuk melihat peningkatannya. Tujuan dari penelitian ini adalah menganalisis perbandingan performansi performansi jaringan di Universitas Tanri Abeng dengan menggunakan protokol routing Statis, OSPF, dan BGP berdasarkan parameter QoS. Pada tahap pengujian menggunakan 8 skenario pengujian untuk setiap metode routing, kemudian untuk setiap skenario melakukan ping 100 kali dengan ukuran paket data 32 byte setiap kali. Hasil pengujian menunjukkan bahwa perutean BGP untuk parameter throughput dan packet loss lebih unggul daripada metode perutean lainnya, sedangkan perutean OSPF untuk parameter penundaan dan jitter lebih unggul daripada metode perutean lainnya.
\end{abstract}

Keyword: Routing, Static, OSPF, BGP

\section{PENDAHULUAN}

Internet menjadi salah satu kebutuhan penting untuk civitas akademika Tanri Abeng University karena menjadi sarana pertukaran informasi. Dengan adanya internet sebagai sarana untuk bertukar informasi menyebabkan semakin banyaknya penggunaan komputer oleh civitas akademika yang menggunakan internet sehingga menyebabkan koneksi jaringan meningkat secara signifikan. Hal ini menyebabkan traffic data menjadi lambat karena semakin banyak pengguna internet. Untuk mengatasi masalah tersebut maka data yang dikirimkan mencari jalan keluar atau sering disebut protokol routing. Salah satu fungsi yang digunakan protokol routing adalah untuk untuk mengatur lalu lintas dalam jaringan komputer.

Protokol routing digunakan untuk menjalankan data dalam sebuah jaringan komputer. Saat ini, Tanri Abeng University menggunakan konfigurasi routing pada router dengan menggunakan routing statis. Kelemahan dari routing statis adalah proses pengisian routing table dilakukan secara manual oleh network administrator. Routing table adalah daftar alamatalamat dari dan kemana suatu paket akan 
diteruskan. Hal ini kurang efektif, dikarenakan dapat memakan waktu yang relatif cukup lama untuk melakukan proses konfigurasinya.

Mengatasi kelemahan pengisian routing table dalam jaringan yang masih menggunakan routing secara manual diperlukan pengisian routing table secara otomatis atau disebut dengan routing dynamic. Routing dynamic merupakan routing yang dilakukan dengan penentuan rute untuk mengirimkan paket data dilakukan secara otomatis berdasarkan informasi dari IP network yang didapat oleh router [1]. Kelebihan dari routing dynamic yaitu membuat update tabel routing secara otomatis jika topologi jaringan juga berubah [2].

Protokol routing dynamic terdiri dari Enhanced Interior Gateway Routing Protocol (EIGRP), Intermediate System-to-Intermediate System (ISIS), Routing Information Protocol (RIP), Border Gateway Protocol (BGP) dan Open Shortest Path First (OSPF). Kelebihan dari protokol routing dinamik OSPF merupakan protokol routing dengan menggunakan link-state yang dibentuk untuk bekerja secara tepat berdasarkan pengiriman update informasi rute [1]. Sedangkan kelebihan dari protokol routing BGP adalah kemampuan untuk bertukar informasi tabel routing antar router tetangga dengan Autonomus System (AS) yang berbeda [3]. Autonomus System (AS) adalah kumpulan router yang mana manajemen router berada dibawah administrasi atau aturan yang sama [3].

Dalam penelitian ini diusulkan perancangan simulasi jaringan komputer dalam pengiriman paket data dengan menggunakan protokol routing statis, Open Shortest Path First (OSPF) dan Border Gateway Protocol (BGP) di Tanri Abeng University. Tujuan dilakukan perancangan simulasi ini adalah membandingkan kinerja jaringan komputer dalam pengiriman paket data dengan menggunakan protokol routing statis, OSPF, dan BGP berdasarkan parameter yang digunakan.

\section{LANDASAN TEORI}

\section{A. Jaringan Komputer}

Jaringan komputer adalah koneksi yang terjadi antara lebih dari 1 komputer menggunakan media transmisi [4]. Contoh dari media transmisi yaitu kabel, gelombang radio dan cahaya tergantung kebutuhan yang digunakan. Tujuan dari jaringan komputer sebagai media untuk komunikasi antara baik menggunakan software maupun hardware. Jaringan komputer mampu terhubung dengan perangkat keras/hardware maupun perangkat lunak/software dari berbagai perangkat vendor, karena telah memiliki standarisasi secara internasional. Sedangkan internet adalah jaringan komunikasi terbesar yang mampu menghubungkan setiap komputer dari satu tempat ke tempat lainnya ke seluruh dunia.

\section{$B$. Routing}

Routing adalah proses yang dilakukan untuk meneruskan paket antar jaringan sehingga menjadi rute tertentu [5]. Dalam melakukan routing membutuhkan router. Router berfungsi untuk melanjutkan paket-paket data dari suatu network ke network yang lainnya, sehingga host antar network dapat saling berkomunikasi [5]. Router dapat menganalisis setiap paket-paket data yang melewati jaringan dan kemudian paket data tersebut akan diarahkan melalui jalur terbaik, sehingga paket data akan sampai ke tujuan [3]. Daftar/list dari jalur-jalur terbaik ini, akan disimpan dalam sebuah tabel yang biasa disebut dengan Routing Information Base (RIB) [3].

\section{Dynamic Routing Protocol}

Dynamic routing protocol merupakan routing yang terjadi dimana router dapat mengetahui rute atau jalur terbaik yang akan dilalui/ditempuh untuk dapat melewatkan paket data antar network [6]. Dynamic routing akan membuat tabel routing secara dinamik (tabel routing berubah-ubah secara otomatis) jika topologi jaringan diubah [6].

Secara garis besar dynamic routing protocol diklasifikasikan menjadi EGP dan IGP, dan kemudian dibedakan menjadi distance vector routing dan state routing [6]. Distance vector routing menggunakan algoritma untuk mengkalkulasi dari nilai kumulatif jarak antar router berdasarkan pada hop count [6]. Hop count merupakan jumlah perangkat perantara yang terdapat di router dan yang harus dilewati antara sumber dan tujuan [7]. Sedangkan link state routing menggunakan algoritma canggih yang memelihara database kompleks dari topologi internetwork [7]. Klasifikasi protokol dynamic routing dalam bentuk Gambar 1 [8]. 


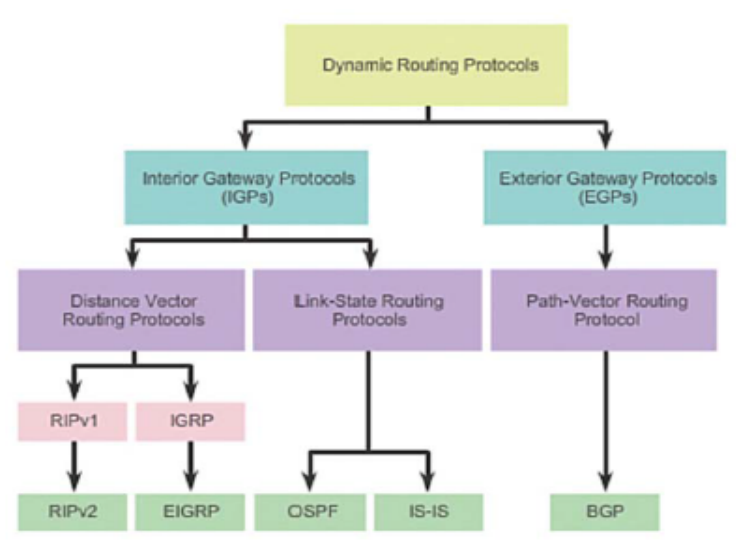

Gambar 1. Klasifikasi Dynamic Routing Protocol [8]

Berikut ini menunjukan posisi kerja dari protokol yang disebutkan dalam network domain [8].

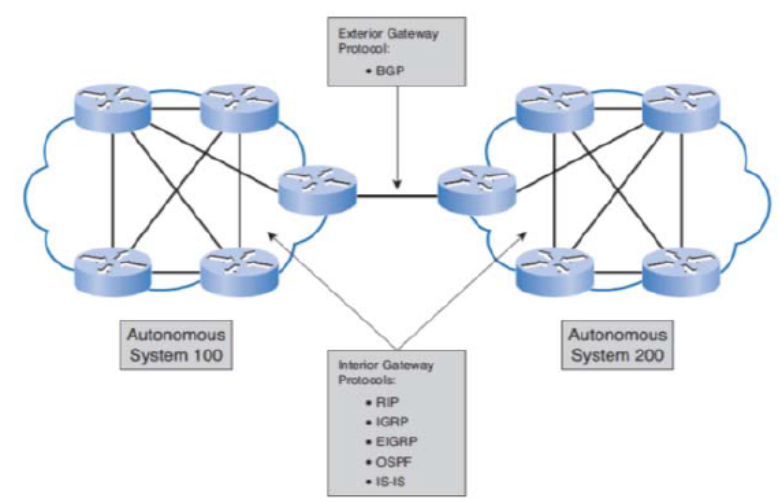

Gambar 2. Posisi Berbagai Protokol Dalam Infrastruktur Jaringan [8]

\section{Open Shortest Path First (OSPF)}

OSPF merupakan suatu protokol routing dynamic yang dikembangkan untuk jaringan atau network berbasis IP oleh Internet Engineering Task Force (IETF) [9]. OSPF juga merupakan suatu protokol routing link state yang diterapkan pada suatu intra autonomus system [10]. Algoritma yang digunakan pada routing OSPF adalah metode link state [10]. OSPF merupakan protokol routing dengan menggunakan link-state yang dibentuk untuk bekerja secara tepat berdasarkan pengiriman update informasi rute [1].

Algoritma OSPF biasaya menggunakan metode link state untuk mengkalkulasi shortest path pada setiap destination node. Pada protokol routing link state mempunyai informasi yang lengkap dan akurat tentang network yang akan dilalui di semua router. Pada Gambar 3 akan dijelaskan skema dari routing OSPF [10].

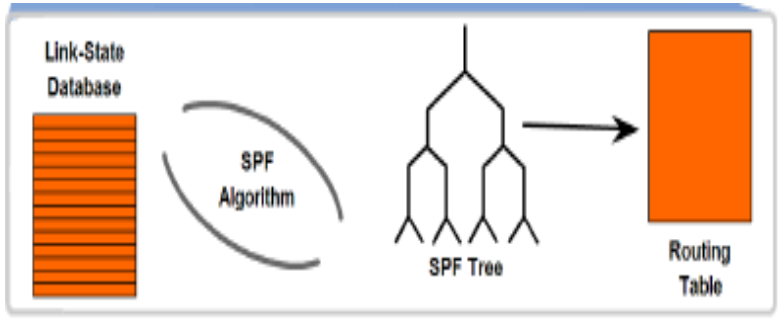

Gambar 3. Skema Routing OSPF [10]

Router menjalankan atau melakukan broadcast mengenai informasi routing kepada setiap router dalam suatu Autonomus System. Jika terjadi perubahan dalam informasi routing maka router mengimkan broadcast ke semua router. Sebuah router akan mengirimkan broadcast link-state ke setiap router lainnya jika terdapat perubahan informasi pada network seperti perubahan cost dan status network yang berubah [10]. Kelebihan dari OSPF yaitu sebagai berikut [8]:

1) OSPF bukan protokol punya Cisco.

2) OPSF selalu menentukan rute atau jalur tercepat.

3) Jika ada perubahan dalam jaringan, maka database diupdate dengan cepat.

4) Menggunakan bandwith yang kecil untuk mengirimkan paket data.

5) Mendukung banyak rute atau jalur untuk sampai ke network tujuan.

6) OSPF didasarkan pada cost interface.

7) Support atau mendukung Variable Length Subnet Mask (VLSM).

Sedangkan kelemahan dari OSPF yaitu sebagai berkut [8]:

1) Konfigurasi routing yang susah.

2) Membutuhkan lebih banyak memori.

\section{E. Border Gateway Protocol (BGP)}

BGP merupakan 55ebagian routing utama yang digunakan di dalam internet [3]. BGP merupakan suatu routing 55ebagian yang berfungsi untuk menjalankan pertukaran tabel routing antar autonomous system. Kelebihan dari routing 55ebagian BGP dibandingkan dengan routing 55ebagian lainnya adalah kemampuan untuk dapat menghindari loop path selection. Loop path selection adalah kejadian yang mana paket data yang dikirim secara terus-menerus dengan rute atau jalur yang berputar-putar [3].

\section{E.1 Operasi BGP}

Ketika kedua router terhubung dengan TCP (Transmision Control Protocol) dan dapat 
mengaktifkan BGP, maka kedua router tersebut dinamakan neighbours dan peers sedangkan yang mengaktifkan BGP dinamakan BGP speaker. Beberapa BGP speaker bisa ditempatkan pada AS yang sama ataupun pada AS yang berbeda. Pada setiap bagian AS, BGP speaker akan berkomunikasi satu dengan yang lainnya, dengan tujuan untuk melakukan pertukaran informasi perihal tabel routing [3].

\section{E.2 Proses Routing BGP}

Terdapat beberapa tahap yang dilakukan BGP ketika melakukan proses routing. Tahap-tahap tersebut dijelaskan sebagai berikut [3]:

\section{E.2.1 Routes Received from Peers}

Pada tahapan ini, router BGP akan menerima informasi terkait routing dari perangkat router pasangannya, baik pada router internal maupun router eksternal. Tahapan ini akan tergantung dari kebijakan yang telah diterapkan atau diimplementasikan oleh router BGP. Selanjutnya, sebagian atau semua informasi routing yang diperoleh akan dimasukkan ke dalam tabel routing [3].

\section{E.2.2 Input Policy Engine}

Pada tahapan ini, router BGP dapat melakukan proses filtering terhadap semua informasi yang diperoleh pada tahapan sebelumnya. Kemudian informasi yang sudah dilakukan proses seleksi, selanjutnya akan menuju ke tahapan berikutnya, yaitu proses penentuan atau pengambilan keputusan berupa rute atau jalur terbaik yang akan dilalui [3].

\section{E.2.3 The Decision Process}

Pada tahapan ini, akan dilakukan proses penentuan atau pengambilan keputusan untuk semua jalur atau rute yang ada. Selanjutnya, pada proses penentuan atau pengambilan keputusan ini, diperoleh berdasarkan informasi dari tahapan sebelumnya. Pada tahapan ini, bertujuan untuk memperoleh lebih dari satu rute atau jalur untuk mencapai tujuan ke network yang telah ditentukan [3].

\section{E.2.4 Routes Used By User}

Setelah memperoleh rute atau jalur yang dapat ditempuh untuk sampai ke network tujuan, selanjutnya pada tahapan ini, informasi itu akan disusun untuk memperoleh rute atau jalur terbaik. Kemudian informasi yang telah diperoleh, lalu akan dimasukkan ke dalam tabel routing. Selanjutnya, informasi hasil seleksi ini nantinya akan diberikan ke BGP pasangannya, setelah melalui atau melewati tahapan berikutnya.

\section{E.2.5 Output Policy Engine}

Pada tahapan ini, seluruh informasi pada routing yang telah diperoleh akan diteruskan atau dilanjutkan ke BGP pasangannya. Lalu akan dilakukan proses seleksi dengan membedakan antara BGP pasangan yang internal maupun yang eksternal. Pada jalur atau rute routing yang berasal dari BGP internal, AS tidak diperkenankan untuk melanjutkan ke pasangan BGP internal. Ini dapat mencegah routing pada loop terjadi lagi [3].

\section{E.2.6 Routes Advertised to Peers}

Pada tahapan akhir ini, seluruh informasi pada routing yang telah diproses, selanjutnya akan diteruskan atau dilanjutkan ke setiap pasangan BGP, baik AS BGP eksternal maupun internal [3], seperti terlihat pada gambar berikut.

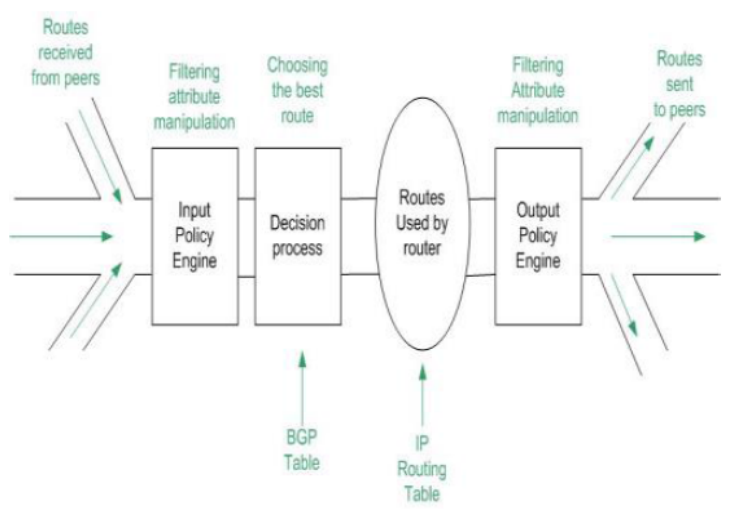

Gambar 4. Diagram Proses Routing BGP [3]

\section{E.3 BGP session}

BGP mengenal dua sesi saat melakukan pertukaran informasi routing, yaitu pertukaran diantara AS yang berbeda dan pertukaran internal AS. Jika BGP dijalankan diantara AS yang berbeda maka akan dinamakan eksternal BGP (EBGP) dan akan membentuk inter-AS routing. Jika BGP digunakan dalam sebuah AS tunggal maka akan dinamakan internal BGP (IBGP) dan akan membentuk intra-AS routing. Berikut merupakan penjelasan mengenai EBGP dan IBGP [3].

\section{E.3.1 Eksternal BGP (EBGP)}

EBGP merupakan sesi router BGP untuk bertukar informasi dengan router AS lain. Setelah mendapatkan informasi routing dari router AS lain, EBGP akan meneruskannya ke IBGP agar informasi tersebut disebarkan ke router-router yang berada didalam AS tersebut. EBGP juga 
berfungsi untuk meneruskan informasi internal AS ke router AS luar sesuai dengan kebijakan yang diterapkan dalam AS tersebut [3].

\section{E.3.2 Internal BGP (IBGP)}

IBGP merupakan sesi router BGP untuk bertukar informasi routing dengan router yang berada di dalam AS tunggal. Fungsi IBGP adalah mengakomodasi kebijakan yang diterapkan dalam sebuah AS ke semua router yang menjadi anggota AS tersebut. Selain itu IBGP juga berfungsi untuk menyebarkan informasi tabel routing yang didapat dari AS lain. Sehingga dengan adanya IBGP, router lain dalam AS dapat mengenal jalurjalur menuju AS lain [3].

\section{METODOLOGI PENELITIAN}

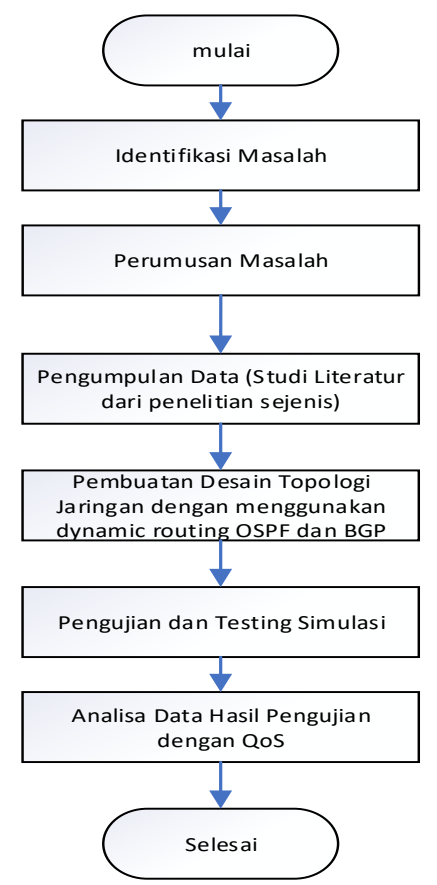

Gambar 5. Rancangan Topologi Jaringan dengan Menggunakan Routing Statis

\section{A. Pembuatan Desain Topologi}

Pada tahap ini peneliti melakukan pengamatan terhadap topologi yang sedang berjalan di TAU. Hal ini ditujukan untuk menemukan masalah yang ada pada topologi tersebut serta merancang solusi untuk masalah tersebut.

A.1 Pembuatan Desain Topologi Jaringan yang sedang berjalan

Pembuatan desain topologi jaringan yang sedang berjalan menggunakan routing statis ditujukan pada gambar 6 . 


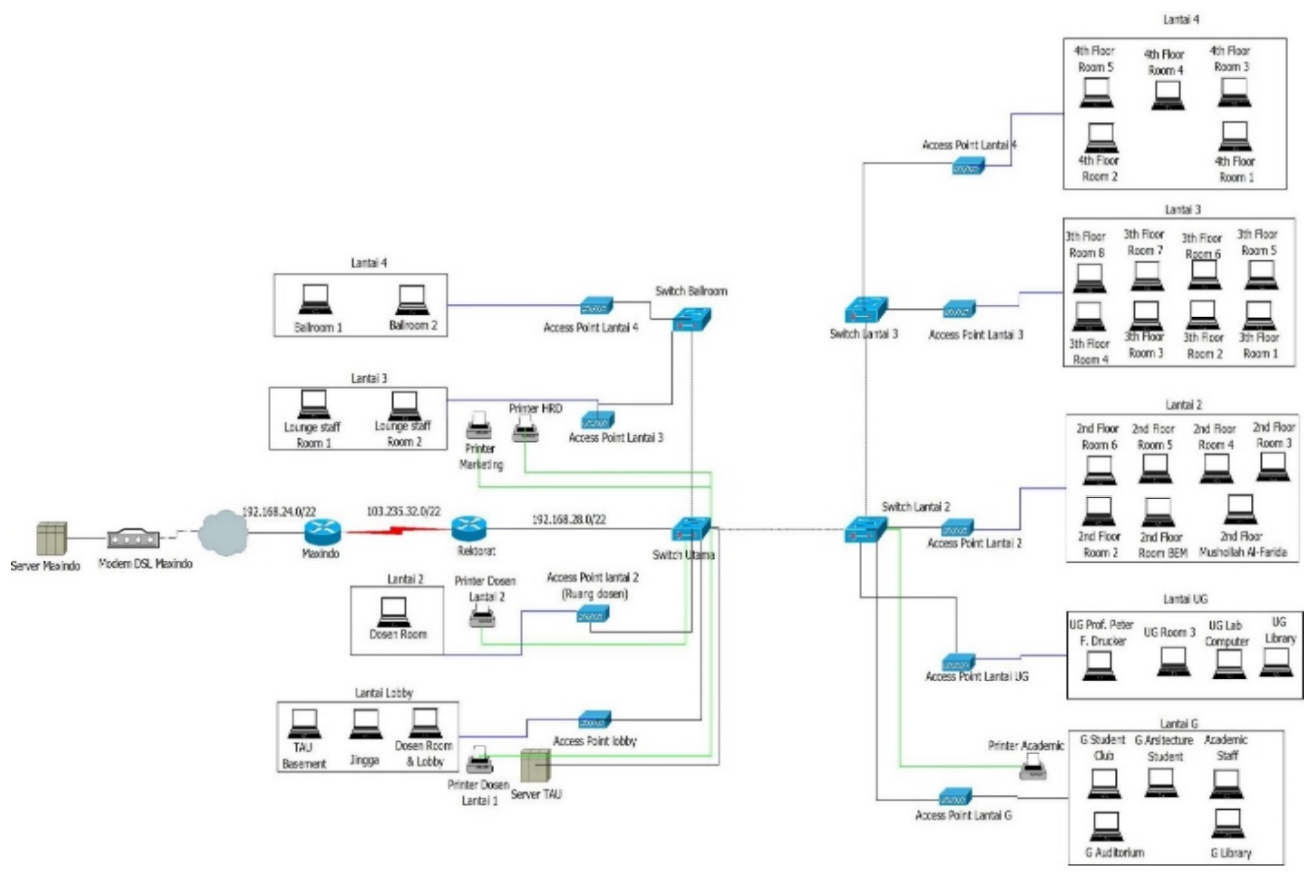

Gambar 6. Rancangan Topologi Jaringan dengan Menggunakan Routing Statis

Berdasarkan topologi yang sedang berjalan saat ini masih terdapat beberapa masalah saat melakukan wawancara dengan pihak IT, antara lain yaitu jika terjadi perubahan atau penambahan network maka proses routing dilakukan secara manual, sehingga dibutuhkan suatu routing yang dapat meningkatkan kinerja jaringan dengan cara melakukan update table routing.

\section{A.2 Rancangan Topologi}

Untuk mengatasai masalah tersebut dirumuskan beberapa solusi pemecahan masalah antara lain yaitu diperlukan sebuah routing dynamic protocol untuk meningkatkan koneksi jaringan. Berikut ini rancangan pembuatan topologi routing yang diusulkan.

A.2.1 Pembuatan Desain Topologi Jaringan dengan Menggunakan OSPF

Membangun topologi jaringan dengan melakukan konfigurasi router maxindo, rektorat dan akademik dengan menggunakan protokol routing OSPF. Perancangan topologi jaringan dengan menggunakan protokol routing OSPF dijabarkan pada gambar 7 .

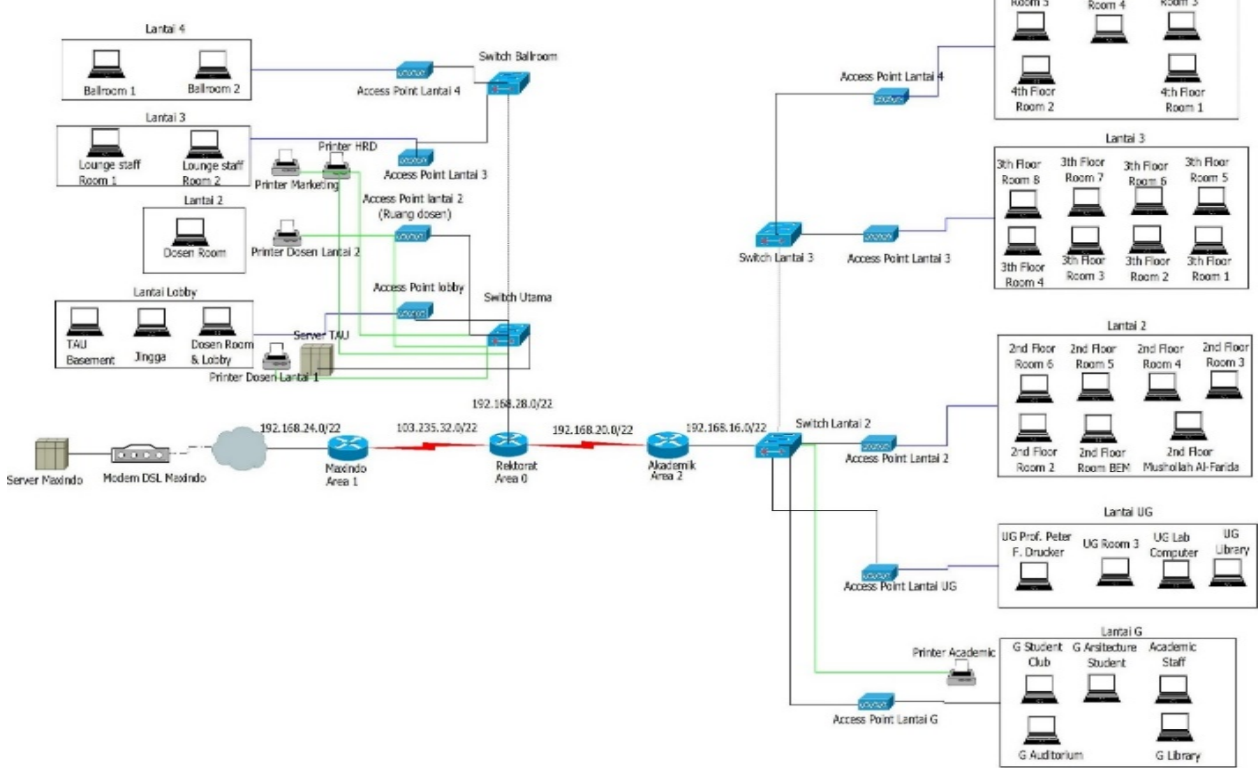

Gambar 7. RancanganTopologi Jaringan dengan Menggunakan Routing OSPF 


\section{Jurnal Sistem Komputer dan Kecerdasan Buatan}

Vol. IV No. 2 Tahun 2021

A.2.2 Pembuatan Desain Topologi Jaringan dengan Menggunakan BGP

Membangun topologi jaringan dengan melakukan konfigurasi router maxindo, rektorat dan akademik dengan menggunakan protokol routing BGP. Perancangan topologi jaringan dengan menggunakan protokol routing BGP dijabarkan pada gambar 8 .

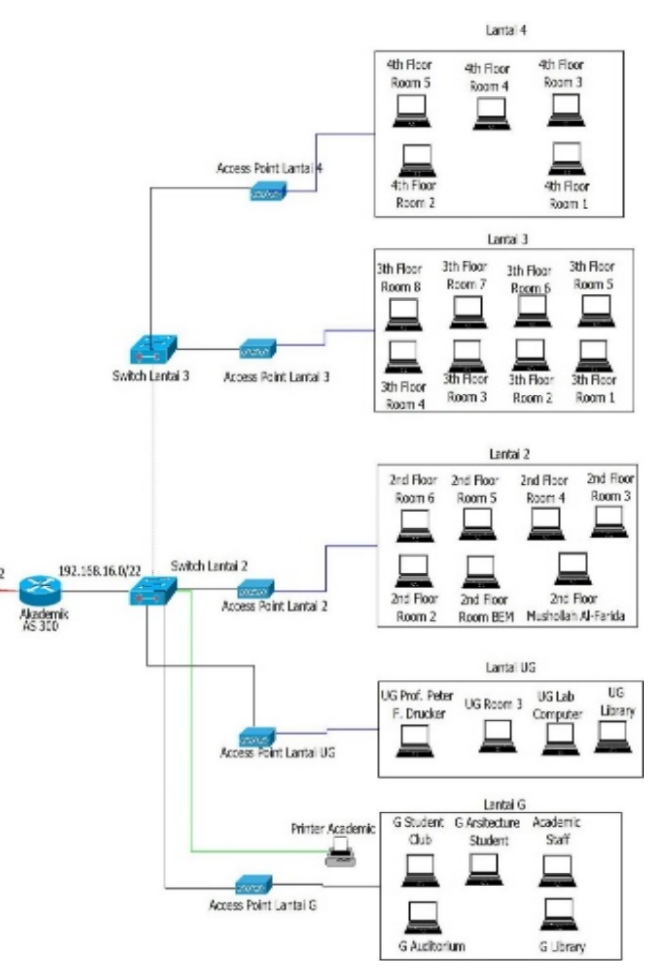

Gambar 8. RancanganTopologi Jaringan dengan Menggunakan Routing BGP

\section{B. Analisis Data Hasil Pengujian}

Pada penelitian ini digunakan parameter yang dapat membantu dalam proses penelitian. Adapapun parameter yang digunanakan yaitu throughput, packet loss, delay dan jitter.

\section{B.1 Throughput}

Throughput merupakan jumlah paket yang sukses diterima berdasarkan interval waktu dibagi dengan interval waktu tersebut [11]. Berikut ini tabel indeks parameter throughput [12].

Tabel 1. Indeks Parameter Throughput [12]

\begin{tabular}{|c|c|c|}
\hline Kategori & Throughput & Indeks \\
\hline Sangat bagus & $100 \%$ & 4 \\
\hline Bagus & $75 \%$ & 3 \\
\hline Sedang & $50 \%$ & 2 \\
\hline Jelek & $<25 \%$ & 1 \\
\hline
\end{tabular}

Persamaan perhitungan throughput:

Throughput $=$ besar data yang dikirim x jumlah paket yang sukses terkirim waktu pengiriman data

B.2 Packet Loss
Packet loss merupakan parameter yang terjadi karena collision dan congestion sehingga mengakibatkan kehilangan jumlah paket data [11]. Berikut ini tabel indeks parameter packet loss [12].

Tabel 2. Indeks Parameter Packet Loss [12]

\begin{tabular}{|c|c|c|}
\hline Kategori & Packet Loss & Indeks \\
\hline Sangat bagus & $0 \%$ & 4 \\
\hline Bagus & $3 \%$ & 3 \\
\hline Sedang & $15 \%$ & 2 \\
\hline Jelek & $25 \%$ & 1 \\
\hline
\end{tabular}

Persamaan perhitungan packet loss:

Packet loss $=$ $\frac{\text { (paket data dikirim-paket data diterima) }}{\text { paket data dikirim }} \times 100 \%$

\section{B.3 Delay (Latency)}

Delay adalah besaran waktu yang dibutuhkan oleh paket data untuk menempuh jarak dari network asal ke network tujuan [11]. Delay dipengaruhi beberapa faktor yaitu jarak, media fisik, kongesti atau waktu dengan proses yang 
lama [11]. Berikut ini tabel indeks parameter delay [12]:

Tabel 3. Indeks Parameter Delay [12]

\begin{tabular}{|c|c|c|}
\hline Kategori & Delay & Indeks \\
\hline Sangat bagus & $0 \%$ & 4 \\
\hline Bagus & $3 \%$ & 3 \\
\hline Sedang & $15 \%$ & 2 \\
\hline Jelek & $25 \%$ & 1 \\
\hline
\end{tabular}

Persamaan perhitungan delay:

delay $=$ waktu penerimaan -

waktu pengiriman

\section{B.4 Jitter}

Jitter adalah variasi yang terjadi dalam panjang antrian, waktu pengolahan data, dan mengumpulkan kembali paket data di akhir perjalanan [11]. Jitter biasanya disebut dengan variasi delay yang berhubungan dengan latency karena karena menunjukan perubahan delay yang begitu banyak pada saat transmisi data dalam jaringan [11]. Berikut ini tabel indeks parameter jitter [12]:

Tabel 4. Indeks Parameter Jitter [12]

\begin{tabular}{|c|c|c|}
\hline Kategori & Jitter & Indeks \\
\hline Sangat bagus & $0 \mathrm{~ms}$ & 4 \\
\hline Bagus & $0 \mathrm{~s} / \mathrm{d} 75 \mathrm{~ms}$ & 3 \\
\hline Sedang & $75 \mathrm{~s} / \mathrm{d} 125 \mathrm{~ms}$ & 2 \\
\hline Jelek & $125 \mathrm{~s} / \mathrm{d} 225 \mathrm{~ms}$ & 1 \\
\hline
\end{tabular}

Persamaan perhitungan jitter:

$$
\text { Jitter }=\frac{\text { total variasi delay }}{\text { total paket yang diterima }}
$$

Total variasi delay diperoleh dari:

total variasi delay $=$ delay - rata - rata delay

\section{IMPLEMENTASI DAN EVALUASI}

Dalam evaluasi pengaruh throughput, packet loss, delay, dan jitter pada routing statis, OSPF, dan BGP dilakukan ping sebanyak 100 kali dengan ukuran paket data yang dikirim sebesar 32 byte. Pada penelitian ini dilakukan skenario pengujian sebanyak delapan kali pada setiap parameter dengan harapan untuk menentukan metode routing manakah yang lebih optimal.
A. Evaluasi Perbandingan Throughput Pada Routing Statis, OSPF dan BGP

Tabel 5. Hasil Evaluasi Perbandingan Throughput Pada Routing Statis, OSPF, dan BGP

\begin{tabular}{|c|c|c|c|c|c|}
\hline \multirow{2}{*}{$\begin{array}{c}\text { Skena } \\
\text { rio } \\
\text { Uji } \\
\text { Coba }\end{array}$} & \multirow{2}{*}{ Sumber } & \multirow{2}{*}{ Tujuan } & \multicolumn{3}{|c|}{ Throughput (bpms) } \\
\hline & & & Statis & OSPF & BGP \\
\hline 1 & $\begin{array}{c}\text { TAU } \\
\text { Basem } \\
\text { ent } \\
\end{array}$ & $\begin{array}{c}\text { Server } \\
\text { Maxindo }\end{array}$ & 48 & 53,69 & 50,28 \\
\hline 2 & Jingga & $\begin{array}{l}\text { Server } \\
\text { Maxindo }\end{array}$ & 47,05 & 52,45 & 50 \\
\hline 3 & $\begin{array}{c}\text { Dosen } \\
\text { Room } \\
\& \\
\text { Lobby } \\
\end{array}$ & $\begin{array}{c}\text { Server } \\
\text { Maxindo }\end{array}$ & 49,23 & 50,79 & 50,79 \\
\hline 4 & $\begin{array}{l}\text { Dosen } \\
\text { Room }\end{array}$ & $\begin{array}{l}\text { Server } \\
\text { Maxindo }\end{array}$ & 49,54 & 53,51 & 54,62 \\
\hline 5 & $\begin{array}{l}\text { Lounge } \\
\text { staff } \\
\text { room } 1\end{array}$ & $\begin{array}{c}\text { Server } \\
\text { Maxindo }\end{array}$ & 47,76 & 47,05 & 45,07 \\
\hline 6 & $\begin{array}{c}\text { Lounge } \\
\text { Staff } \\
\text { Room } \\
2 \\
\end{array}$ & $\begin{array}{c}\text { Server } \\
\text { Maxindo }\end{array}$ & 46,37 & 47,05 & 46,37 \\
\hline 7 & $\begin{array}{c}\text { Ballroo } \\
\text { m } 1\end{array}$ & $\begin{array}{c}\text { Server } \\
\text { Maxindo }\end{array}$ & 45,71 & 48,48 & 45,71 \\
\hline 8 & $\begin{array}{c}\text { Ballroo } \\
\mathrm{m} 2\end{array}$ & $\begin{array}{c}\text { Server } \\
\text { Maxindo }\end{array}$ & 44,44 & 49,23 & 47,05 \\
\hline \multicolumn{3}{|c|}{ Rata-Rata } & 48 & 44,44 & 50 \\
\hline \multicolumn{3}{|c|}{$\begin{array}{l}\text { Kategori Indeks Parameter } \\
\text { Throughput }\end{array}$} & Sedang & Sedang & Sedang \\
\hline
\end{tabular}

Berdasarkan tabel 5 diatas dijelaskan mengenai hasil evaluasi pengaruh throughput terhadap routing protokol dalam menguji kinerja jaringan didapatkan hasil bahwa rata-rata nilai throughput dari jaringan yang menggunakan routing statis adalah 48 bpms dengan kategori indeks parameter throughput sedang, jaringan yang menggunakan routing OSPF adalah 44,44 bpms dengan kategori indeks parameter throughput sedang, sedangkan jaringan yang menggunakan routing BGP adalah $50 \mathrm{bpms}$ dengan kategori indeks parameter throughput sedang. Jaringan yang menggunakan protokol routing BGP memiliki tingkat kinerja jaringan yang lebih baik untuk parameter throughput dikarenakan mempunyai nilai throughput yang besar berdasarkan standarisasi TIPHON (Telecommunications and Internet Protocol Harmonization Over Network). Semakin besar nilai throughput dari metode routing yang digunakan menyebabkan tingkat kinerja jaringan lebih baik dan begitupun sebaliknya jika nilai throughput dari metode routing yang digunakan semakin kecil menyebabkan tingkat kinerja jaringan kurang baik. 
B. Evaluasi Perbandingan Packet Loss Pada Routing Statis, OSPF dan BGP

Tabel 6. Hasil Evaluasi Perbandingan Packet Loss Pada Routing Statis, OSPF, dan BGP

\begin{tabular}{|c|c|c|c|c|c|}
\hline $\begin{array}{l}\text { Skena } \\
\text { rio }\end{array}$ & \multirow{2}{*}{ Sumber } & \multirow{2}{*}{ Tujuan } & \multicolumn{3}{|c|}{ Packet Loss (\%) } \\
\hline Coba & & & Statis & OSPF & BGP \\
\hline 1 & $\begin{array}{c}\text { TAU } \\
\text { Basemen } \\
\mathrm{t}\end{array}$ & $\begin{array}{c}\text { Server } \\
\text { Maxindo }\end{array}$ & 1 & 1 & 1 \\
\hline 2 & Jingga & $\begin{array}{l}\text { Server } \\
\text { Maxindo }\end{array}$ & 0 & 0 & 0 \\
\hline 3 & $\begin{array}{c}\text { Dosen } \\
\text { Room \& } \\
\text { Lobby }\end{array}$ & $\begin{array}{c}\text { Server } \\
\text { Maxindo }\end{array}$ & 0 & 0 & 0 \\
\hline 4 & $\begin{array}{l}\text { Dosen } \\
\text { Room }\end{array}$ & $\begin{array}{l}\text { Server } \\
\text { Maxindo }\end{array}$ & 4 & 3 & 1 \\
\hline 5 & $\begin{array}{l}\text { Lounge } \\
\text { staff } \\
\text { room } 1\end{array}$ & $\begin{array}{c}\text { Server } \\
\text { Maxindo }\end{array}$ & 0 & 0 & 0 \\
\hline 6 & $\begin{array}{c}\text { Lounge } \\
\text { Staff } \\
\text { Room } 2 \\
\end{array}$ & $\begin{array}{c}\text { Server } \\
\text { Maxindo }\end{array}$ & 0 & 0 & 0 \\
\hline 7 & $\begin{array}{c}\text { Ballroo } \\
\mathrm{m} 1\end{array}$ & $\begin{array}{l}\text { Server } \\
\text { Maxindo }\end{array}$ & 0 & 0 & 0 \\
\hline 8 & $\begin{array}{c}\text { Ballroo } \\
\mathrm{m} 2\end{array}$ & $\begin{array}{c}\text { Server } \\
\text { Maxindo }\end{array}$ & 0 & 0 & 0 \\
\hline \multicolumn{3}{|c|}{ Rata-Rata } & 0,625 & 0,5 & 0,25 \\
\hline \multicolumn{3}{|c|}{$\begin{array}{c}\text { Kategori Indeks Parameter } \\
\text { Packet Loss }\end{array}$} & $\begin{array}{l}\text { Sangat } \\
\text { bagus }\end{array}$ & $\begin{array}{l}\text { Sangat } \\
\text { bagus }\end{array}$ & $\begin{array}{l}\text { Sangat } \\
\text { bagus }\end{array}$ \\
\hline
\end{tabular}

Berdasarkan tabel 6 diatas dijelaskan mengenai hasil eveluasi pengaruh packet loss terhadap routing protokol dalam menguji kinerja jaringan didapatkan hasil bahwa rata-rata nilai packet loss dari jaringan yang menggunakan routing statis adalah $0,625 \%$ dengan kategori indeks parameter packet loss sangat bagus, jaringan yang menggunakan routing OSPF adalah $0,5 \%$ dengan kategori indeks parameter packet loss sangat bagus, sedangkan jaringan yang menggunakan routing BGP adalah $0,25 \%$ dengan kategori indeks parameter packet loss sangat bagus. Jaringan yang menggunakan protokol routing BGP memiliki tingkat kinerja jaringan yang lebih baik untuk parameter packet loss dikarenakan mempunyai nilai packet loss yang lebih kecil berdasarkan standarisasi TIPHON (Telecommunications and Internet Protocol Harmonization Over Network). Semakin kecil nilai packet loss dari metode routing yang digunakan menyebabkan tingkat kinerja jaringan lebih baik dan begitupun sebaliknya jika nilai packet loss dari metode routing yang digunakan semakin besar menyebabkan tingkat kinerja jaringan kurang baik.

\section{Evaluasi Perbandingan Delay Pada Routing Statis, OSPF dan BGP}

Berdasarkan tabel 7 dijelaskan mengenai hasil eveluasi pengaruh delay terhadap routing protokol dalam menguji kinerja jaringan didapatkan hasil bahwa rata-rata nilai delay dari jaringan yang menggunakan routing statis adalah 76,375 ms dengan kategori indeks parameter delay sangat bagus, jaringan yang menggunakan routing OSPF adalah 63,5 ms dengan kategori indeks parameter delay sangat bagus, sedangkan jaringan yang menggunakan routing BGP adalah 65,75 ms dengan kategori indeks parameter delay sangat bagus. Jaringan yang menggunakan protokol routing OSPF memiliki tingkat kinerja jaringan yang lebih baik untuk parameter delay dikarenakan mempunyai nilai delay yang lebih kecil berdasarkan standarisasi TIPHON (Telecommunications and Internet Protocol Harmonization Over Network). Semakin kecil nilai delay dari metode routing yang digunakan menyebabkan tingkat kinerja jaringan lebih baik dan begitupun sebaliknya jika nilai delay dari metode routing yang digunakan semakin besar meyebabkan tingkat kinerja jaringan kurang baik

Tabel 7. Hasil Evaluasi Perbandingan Delay Pada Routing Statis, OSPF, dan BGP

\begin{tabular}{|c|c|c|c|c|c|}
\hline \multirow{2}{*}{$\begin{array}{c}\text { Skenario } \\
\text { Uji } \\
\text { Coba }\end{array}$} & \multirow{2}{*}{ Sumber } & \multirow{2}{*}{ Tujuan } & \multicolumn{3}{|c|}{ Delay (ms) } \\
\hline & & & Statis & OSPF & BGP \\
\hline 1 & $\begin{array}{c}\text { TAU } \\
\text { Basement }\end{array}$ & $\begin{array}{c}\text { Server } \\
\text { Maxindo }\end{array}$ & 66 & 59 & 63 \\
\hline 2 & Jingga & $\begin{array}{c}\text { Server } \\
\text { Maxindo }\end{array}$ & 68 & 61 & 64 \\
\hline 3 & $\begin{array}{c}\text { Dosen } \\
\text { Room \& } \\
\text { Lobby }\end{array}$ & $\begin{array}{c}\text { Server } \\
\text { Maxindo }\end{array}$ & 65 & 63 & 63 \\
\hline 4 & $\begin{array}{l}\text { Dosen } \\
\text { Room }\end{array}$ & $\begin{array}{c}\text { Server } \\
\text { Maxindo }\end{array}$ & 62 & 58 & 58 \\
\hline 5 & $\begin{array}{c}\text { Lounge } \\
\text { staff room } \\
1 \\
\end{array}$ & $\begin{array}{c}\text { Server } \\
\text { Maxindo }\end{array}$ & 67 & 68 & 71 \\
\hline 6 & $\begin{array}{l}\text { Lounge } \\
\text { Staff } \\
\text { Room } 2\end{array}$ & $\begin{array}{c}\text { Server } \\
\text { Maxindo }\end{array}$ & 69 & 68 & 69 \\
\hline 7 & $\begin{array}{c}\text { Ballroom } \\
1\end{array}$ & $\begin{array}{c}\text { Server } \\
\text { Maxindo }\end{array}$ & 70 & 66 & 70 \\
\hline 8 & $\begin{array}{c}\text { Ballroom } \\
2\end{array}$ & $\begin{array}{c}\text { Server } \\
\text { Maxindo }\end{array}$ & 72 & 65 & 68 \\
\hline \multicolumn{3}{|c|}{ Rata-Rata } & 67.375 & 63.5 & 65.75 \\
\hline \multicolumn{3}{|c|}{ Kategori Indeks Parameter Delay } & $\begin{array}{l}\text { Sangat } \\
\text { bagus }\end{array}$ & $\begin{array}{l}\text { Sangat } \\
\text { bagus }\end{array}$ & $\begin{array}{l}\text { Sangat } \\
\text { bagus }\end{array}$ \\
\hline
\end{tabular}

4.4 Evaluasi Perbandingan Jitter Pada Routing Statis, OSPF dan BGP 
Berdasarkan tabel 8 diatas dijelaskan mengenai hasil eveluasi pengaruh jitter terhadap routing protokol dalam menguji kinerja jaringan didapatkan hasil bahwa rata-rata nilai jitter dari jaringan yang menggunakan routing statis adalah 0,66 ms dengan kategori indeks parameter jitter sangat bagus, jaringan yang menggunakan routing OSPF adalah $0,655 \mathrm{~ms}$ dengan kategori indeks parameter jitter sangat bagus, sedangkan jaringan yang menggunakan routing BGP adalah $0,695 \mathrm{~ms}$ dengan kategori indeks parameter jitter sangat bagus. Jaringan yang menggunakan protokol routing OSPF memiliki tingkat kinerja jaringan yang lebih baik untuk parameter jitter dikarenakan mempunyai nilai jitter yang lebih kecil berdasarkan standarisasi TIPHON (Telecommunications and Internet Protocol Harmonization Over Network). Semakin kecil nilai jitter dari metode routing yang digunakan menyebabkan tingkat kinerja jaringan lebih baik dan begitupun sebaliknya jika nilai jitter dari metode routing yang digunakan semakin besar meyebabkan tingkat kinerja jaringan kurang baik.

Tabel 8. Hasil Evaluasi Perbandingan Jitter Pada Routing Statis, OSPF, dan BGP

\begin{tabular}{|c|c|c|c|c|c|}
\hline \multirow{2}{*}{$\begin{array}{c}\text { Skena } \\
\text { rio uji } \\
\text { coba }\end{array}$} & \multirow{2}{*}{ Sumber } & \multirow{2}{*}{ Tujuan } & \multicolumn{3}{|c|}{ Jitter (ms) } \\
\hline & & & Statis & OSPF & BGP \\
\hline 1 & $\begin{array}{c}\text { TAU } \\
\text { Basemen } \\
\mathrm{t}\end{array}$ & $\begin{array}{l}\text { Server } \\
\text { Maxindo }\end{array}$ & 0.66 & 0,59 & 0,63 \\
\hline 2 & Jingga & $\begin{array}{c}\text { Server } \\
\text { Maxindo }\end{array}$ & 0,68 & 0,61 & 0,64 \\
\hline 3 & $\begin{array}{c}\text { Dosen } \\
\text { Room \& } \\
\text { Lobby }\end{array}$ & $\begin{array}{l}\text { Server } \\
\text { Maxindo }\end{array}$ & 0,65 & 0,63 & 0,63 \\
\hline 4 & $\begin{array}{l}\text { Dosen } \\
\text { Room }\end{array}$ & $\begin{array}{c}\text { Server } \\
\text { Maxindo }\end{array}$ & 0,64 & 0,59 & 0,58 \\
\hline 5 & $\begin{array}{l}\text { Lounge } \\
\text { staff } \\
\text { room } 1\end{array}$ & $\begin{array}{l}\text { Server } \\
\text { Maxindo }\end{array}$ & 0,67 & 0,68 & 0.71 \\
\hline 6 & $\begin{array}{c}\text { Lounge } \\
\text { Staff } \\
\text { Room } 2\end{array}$ & $\begin{array}{l}\text { Server } \\
\text { Maxindo }\end{array}$ & 0,69 & 0,68 & 0.69 \\
\hline 7 & $\begin{array}{c}\text { Gedung } \\
\text { Rektorat } \\
\text { B } \\
\text { Ballroo } \\
\text { m } 1\end{array}$ & $\begin{array}{c}\text { Server } \\
\text { Maxindo }\end{array}$ & 0,7 & 0.66 & 0.7 \\
\hline 8 & $\begin{array}{l}\text { Ballroo } \\
\mathrm{m} 2\end{array}$ & $\begin{array}{c}\text { Server } \\
\text { Maxindo }\end{array}$ & 0,72 & 0.65 & 0.68 \\
\hline \multicolumn{3}{|c|}{ Rata-Rata } & 0,66 & 0,655 & 0,695 \\
\hline \multicolumn{3}{|c|}{$\begin{array}{c}\text { Kategori indeks parameter } \\
\text { Jitter }\end{array}$} & $\begin{array}{l}\text { Sangat } \\
\text { bagus }\end{array}$ & $\begin{array}{l}\text { Sangat } \\
\text { bagus }\end{array}$ & $\begin{array}{l}\text { Sangat } \\
\text { bagus }\end{array}$ \\
\hline
\end{tabular}

\section{KESIMPULAN DAN SARAN}

\section{A. Kesimpulan}

Berdasarkan hasil simulasi yang telah dilakukan, dapat diambil beberapa kesimpulan sebagai berikut:

1. Telah dianalisa topologi jaringan di Tanri Abeng Uiversity menggunakan routing statis. Kelemahan dari routing statis adalah proses pengisian routing table dilakukan secara manual oleh network administrator. Routing table adalah daftar alamat-alamat dari dan kemana suatu paket akan diteruskan. Hal ini kurang efektif dan efisien karena akan memakan waktu yang cukup lama untuk melakukan konfigurasi. Sehingga diperlukan suatu routing yang dapat secara otomatis mengirimkan data berdasarkan routing table. Kelebihan dari protokol routing OSPF merupakan protokol routing dengan menggunakan link-state yang dibentuk untuk bekerja secara tepat berdasarkan pengiriman update informasi rute. Sedangkan kelebihan dari protokol routing BGP adalah kemampuan untuk bertukar informasi routing table antar router tetangga dengan Autonomus System (AS) yang berbeda.

2. Berdasarkan empat parameter yang telah diujikan dalam delapan skenario pengujian untuk routing statis, OSPF, dan BGP dapat ditarik kesimpulan bahwa routing BGP lebih baik dalam pengujian parameter throughput dengan nilai 50bpms dengan kategori indeks parameter sedang berdasarkan standarisasi TIPHON (Telecommunications and Internet Protocol Harmonization Over Network) dan packet loss dengan nilai $0,25 \%$ dalam kategori indeks parameter sangat bagus berdasarkan standarisasi THIPON (Telecommunications and Internet Protocol Harmonization Over Network), sedangkan untuk routing OSPF lebih baik dalam pengujian parameter delay dengan nilai $63,5 \mathrm{~ms}$ dalam kategori indeks sangat bagus berdasarkan standarisasi TIPHON (Telecommunications and Internet Protocol Harmonization Over Network) dan jitter dengan nilai $0,655 \mathrm{~ms}$ dalam kategori indeks parameter sangat bagus berdasarkan standarisasi THIPON (Telecommunications and Internet Protocol Harmonization Over Network). Routing OSPF dan BGP masingmasing mempunyai kelebihan yaitu dapat diterapkan kedalam jaringan dengan ruang 
lingkup yang berbeda-beda. Untuk routing OSPF diterapkan ke dalam ruang lingkup jaringan yang lebih kecil sedangkan untuk routing BGP diterapkan ke dalam ruang lingkup jaringan yang jauh lebih besar. Jika diterapkan ke dalam Tanri Abeng University yang mempunyai ruang lingkup yang kecil maka routing OSPF lebih optimal dibandingakan dengan routing BGP dilihat dari ruang lingkup jaringan yang digunakan.

B. Saran

Berdasarkan hasil penelitian yang telah dilakukan oleh peneliti, berikut ini beberapa saran untuk pengembangan simulasi dynamic routing, antara lain:

1. Dibutuhkan studi kasus nyata dalam penerapan metode routing dinamis OSPF dan BGP sehingga dapat dinilai efektifitas dan efsiensi serta dampak dari konfigurasi router yang digunakan secara nyata, karena mungkin nilai dari hasil uji coba simulasi dengan cisco packet tracer berbeda dengan kenyataan di lapangan.

2. Untuk proses pengiriman paket data dapat dilakukan dengan menggunakan berbagai skenario pengiriman paket data dengan ukuran data yang berbeda-beda.

\section{DAFTAR PUSTAKA}

[1] Jati, W. S., Nurwasito, H. \& Data, M., 2018. Perbandingan Kinerja Protocol Routing Open Shortest Path First (OSPF) dan Routing Information Protocol (RIP) Menggunakan Simulator Cisco Packet Tracer. Jurnal Pengembangan Teknologi Informasi dan Ilmu Komputer, Volume Vol. 2, No. 8.

[2] Musril, H. A., 2015. Analisis Unjuk Keja RIPv2 dan EIGRP Dalam Dynamic Routing Protocol. Jurnal Elektro Telekomunikasi Terapan, p. 118.

[3] Krisnawijaya, N. N. K. \& Paramartha, C. R. A., 2016. PENERAPAN JARINGAN
MULTIHOMING PADA JARINGAN KOMPUTER FAKULTAS HUKUM. JIILK Universitas Udayana Vol. 9, No. 1.

[4] Permana, A. P. N. \& Firmansyah, R., 2018. Distribusi Jaringan Dengan Menggunakan Routing OSPF Dengan Metode Redistribution. Bandung, ISSN: 2252-4983.

[5] Hasanah, F. U. \& Mubarakah, N., 2014. ANALISIS KINERJA ROUTING DINAMIS DENGAN TEKNIK RIP (ROUTING INFORMATION PROTOCOL) PADA TOPOLOGI. SINGUDA ENSIKOM, Volume Vol. 7 No. 3.

[6] Musril, H. A., 2015. Analisis Unjuk Keja RIPv2 dan EIGRP Dalam Dynamic Routing Protocol. Jurnal Elektro Telekomunikasi Terapan, p. 118.

[7] Werluka, N. R., 2015. Implementasi Hop Count Pada Routing Information.

[8] Asher, P., 2015. Comprehensive Analysis of Dynamic Routing Protocol in Computer Network. Mumbai, ISSN:0975-9646, pp. Hal 4450-4455.

[9] Wijaya, C., 2011. Simulasi Pemanfaatan Dynamic Routing Protocol. p. 8.

[10] Alvionita, S. \& Nurwasito, H., 2019. Analisis Kinerja Protokol Routing OSPF, RIP, dan EIGRP Pada Topologi Jaringan Mesh. Malang, e-ISSN: 2548-964X, p. 7446.

[11] Yanto, 2013. Analisis QOS (Quality Of Service) Pada Jaringan Internet (Studi Kasus: Fakultas Teknik Universitas Tanjungpura). Jurusan Teknik Elektro Fakultas Teknik Universitas Tanjungpura, pp. 2-3.

[12] TIPHON, 1999. Telecommunications and Internet Protocol Harmonization Over Network General aspects of Quality of Service. DTR/TIPHON-05006 (cb0010cs.PDF).1999. ed. s.1.:s.n. 